\title{
PHENOTYPIC AND GENOTYPIC CHARACTERIZATION OF SALMONELLA ENTERITIDIS ISOLATES
}

\author{
Sílvia Dias de Oliveiraa ${ }^{1,2 *}$; Marjo Cadó Bessa ${ }^{4}$; Luciana Ruschel dos Santos ${ }^{5}$; Marisa Ribeiro de Itapema Cardoso ; \\ Adriano Brandelli²; Cláudio Wageck Canal ${ }^{3}$
}

${ }^{1}$ Faculdade de Biociências, Pontifícia Universidade Católica do Rio Grande do Sul, Porto Alegre, RS, Brasil; ${ }^{2}$ Departamento de Ciência de Alimentos, Instituto de Ciência e Tecnologia de Alimentos, Universidade Federal do Rio Grande do Sul, Porto Alegre, RS, Brasil; ' ${ }^{3}$ Setor de Virologia, Faculdade de Veterinária, Universidade Federal do Rio Grande do Sul, Porto Alegre, RS, Brasil; ${ }^{4}$ Setor de Medicina Veterinária Preventiva, Universidade Federal do Rio Grande do Sul, Porto Alegre, RS, Brasil; ${ }^{5}$ Universidade de Passo Fundo, Passo Fundo, RS, Brasil

Submitted: February 28, 2007; Returned to authors for corrections: May 19, 2007; Approved: September 20, 2007.

\begin{abstract}
In order to study the epidemiology of Salmonella Enteritidis outbreaks and determine the source of contamination so that a recurrence can be avoided, detailed characterization is necessary. Thus, the purpose of this study was to verify whether rep-PCR was able to discriminate among Salmonella Enteritidis isolates. Phage typing, detection of virulence genes and antimicrobial resistance testing were also associated to repPCR results. One hundred and two $S$. Enteritidis isolates from broiler carcasses, food, human, pigs, poultryrelated samples, and nine isolates from other countries were genotypically typed by REP-PCR, ERIC-PCR and BOX-PCR, collectively called rep-PCR. Phage typing, detection of virulence genes and antimicrobial resistance testing were also performed. Only three fingerprinting profiles were obtained with each rep-PCR method, with the majority of isolates belonging to the same profile. No relationship was observed between genotypic profile and year, place of isolation or source of infection. However, the less frequent rep-PCR profiles showed single antimicrobial resistance patterns. Although few strains isolated from swine were analyzed, different antimicrobial resistance patterns were observed. Furthermore, phage type 4 was not found in swine isolates. rep-PCR showed a lower discriminatory power as compared with antimicrobial resistance and phage typing, but the combination of genotypic and phenotypic methods was more discriminatory than any method alone, resulting in 48 different types.
\end{abstract}

Key words: Salmonella Enteritidis, rep-PCR, phage typing, antimicrobial resistance, virulence genes

\section{INTRODUCTION}

There has been a dramatic increase in the incidence of Salmonella Enteritidis worldwide since 1980 (3,14,25,28). In Brazil, the increase in the incidence of $S$. Enteritidis from foodborne outbreaks, human infections, non-human sources, broiler carcasses and other poultry materials has been reported since the 90's $(5,6,25,29,33,34)$, and poultry is likely the main source of human infections (10). Typing of bacteria can be used to determine whether isolates recovered from different patients or from the environment are related and, in so doing, provide evidence for a common source of transmission of the agent (9). Many phenotypic and genotypic typing methods have been applied to epidemiologically trace $S$. Enteritidis infections. Traditional epidemiological methods include biotyping, serotyping and phage typing of isolates, as well as antimicrobial resistance testing, although these methods do not always give enough information for epidemiological purposes. The limitations of phenotypic analysis have led to the progressive development of genotypic strategies.

*Corresponding Author. Mailing address: Faculdade de Biociências, Pontifícia Universidade Católica do Rio Grande do Sul (PUCRS), Av. Ipiranga 6681, 90619-900, Porto Alegre, Brasil. Tel.: +55-51-30263242; Fax: +55-51-33087305. E-mail: silviadias@ pucrs.br 
Genotypic methods include analysis of plasmid content and plasmid restriction patterns (17), random amplified polymorphic DNA analysis (14), IS 200 typing and ribotyping (20), restriction fragment length polymorphism (RFLP) (36), pulsed-field gel electrophoresis (PFGE) $(7,15,35)$, amplified-fragment length polymorphism (AFLP) (15), multilocus sequence typing of bacterial DNA (19) and repetitive-sequence polymerase chain reaction (rep-PCR) $(26,38,39)$.

Among the molecular methods for typing bacteria, the REP-, ERIC- and BOX-PCR (collectively referred to as repPCR) genomic fingerprinting have been found to be extremely reliable, reproducible, rapid and highly discriminatory $(38,39)$. This method is based on the amplification of DNA sequences by PCR with primer sets complementary to naturally occurring, highly conserved, repetitive DNA sequences present in multiple copies in distinct intergenic positions in the genomes of most Gram negative and several Gram positive bacteria (18).

The purpose of the present study was to asses the level of genetic diversity and possible relationships among $S$. Enteritidis strains isolated from food, human, pigs, broiler carcasses and poultry-related samples using rep-PCR. Phage typing, detection of virulence genes and antimicrobial resistance testing were associated with the results of rep-PCR.

\section{MATERIALS AND METHODS}

\section{Bacterial isolates and growth conditions}

Our study was carried out using a total of 111 Salmonella Enteritidis isolates, being 102 isolates from Southern Brazil (Rio Grande do Sul and Santa Catarina States) collected over the period 1995-2001 (Table 1). Seventeen isolates were from human samples; 31 from food involved in foodborne outbreaks; 22 from broiler carcasses; 11 from pigs (lymph nodes, faeces and fresh pork sausage); and 21 were from other poultry-related samples (viscera and environmental samples). Human and food isolates did not belong to the same outbreak. Furthermore, nine epidemiologically unrelated isolates from other countries (Zimbabwe, Egypt, Tanzania, Italy and Albania) were analyzed. An outgroup of four different serovars of Salmonella (Panama, Bredeney, Agona and Typhimurium) and $S$. Enteritidis ATCC 13076 were also included. The isolates from human samples, food, broiler carcasses and poultry had been phage typed in a previous study (31) and had also their antimicrobial resistance determined (23). For genotyping analysis, all isolates were cultured in TSB and incubated overnight at $37^{\circ} \mathrm{C}$.

\section{Phage typing}

Seven of 11 isolates from swine and the isolates from other countries were phage typed in this study. Phage typing was made as described by Santos et al. (2003).

\section{Antimicrobial susceptibility testing}

The $11 S$. Enteritidis isolated from swine and the nine isolates from other countries were tested for antimicrobial susceptibility. The test was performed according to the guidelines of the National Committee for Clinical Laboratory Standards (22) for the disk diffusion technique using commercial disks. The antimicrobials tested were: ampicillin (Ampc), cephalotin (Cef), ciprofloxacin (Cipx), chloramphenicol (Chl), gentamicin (Gen), streptomycin (Str), nitrofurantoin (Nit), norfloxacin (Nor), nalidixic acid (Nalx), tetracycline (Tet), and sulphonamide (Smx). Inhibition zones were measured and scored as sensitive, intermediate and resistant according to the NCCLS recommendations. Escherichia coli ATCC 25922 was used as a reference strain for antibiotic disc control.

\section{Detection of virulence genes}

The detection of $i n v \mathrm{~A}, s p v \mathrm{R}$ and $s p v \mathrm{C}$ virulence genes was performed in the isolates from other countries. These genes were detected by PCR as previously described for other $S$. Enteritidis strains that belonged to this study (24).

\section{rep-PCR fingerprinting}

A $1 \mathrm{~mL}$ aliquot of culture was centrifuged at $8,000 \mathrm{~g}$ for 10 min. Cells were washed twice in $1 \mathrm{~mL}$ of $1 \mathrm{M} \mathrm{NaCl}$ and pelleted by centrifugation at $8,000 \mathrm{~g}$ for $10 \mathrm{~min}$. Cells were resuspended in $100 \mu \mathrm{L}$ of TE (10 mM Tris $\mathrm{HCl} \mathrm{pH} 8.0,1 \mathrm{mM}$ EDTA). Total DNA was prepared according to the method of Rademaker and de Bruijn (1997). Briefly, bacterial cells were lysed with $500 \mu \mathrm{L}$ of $5 \mathrm{M}$ guanidine thiocyanate, $0.03 \mathrm{M}$ N-lauroyl sarkosine, $0.1 \mathrm{M}$ EDTA, for $5 \mathrm{~min}$ at $4^{\circ} \mathrm{C}$. After, $250 \mu \mathrm{L}$ cold $7.5 \mathrm{M}$ ammonium acetate were added, tubes were gently shaken and incubated for $5 \mathrm{~min}$ at $4^{\circ} \mathrm{C}$. An aliquot of $500 \mu \mathrm{L}$ of chloroform/iso-amylalcohol (24:1) was added and the mixture was vortexed vigorously. After centrifugation at $16,000 \mathrm{~g}$ for $10 \mathrm{~min}$, the DNAcontaining pellet was further washed with isopropyl alcohol. DNA concentration was determined by spectrofluorimetry at excitation and emission wavelenghts of $365 \mathrm{~nm}$ and $460 \mathrm{~nm}$, respectively, using the DNA-specific dye Hoechst 33258 (Amersham Pharmacia Biotech), in a DyNA Quant ${ }^{\mathrm{TM}} 200$ fluorometer (Hoefer Pharmacia Biotech Inc.) according to manufacturer's instructions. DNA concentration was adjusted to $200 \mathrm{ng} / \mu \mathrm{L}$. REP (REP1R-I and REP2-I), ERIC (ERIC1R and ERIC2) and BOX (BOXA1R) primer sequences (Life Technologies) were as previously described (39). PCR was performed in a $25 \mu \mathrm{L}$ reaction volume containing Gitschier buffer $\left(16.6 \mathrm{mM}\left(\mathrm{NH}_{4}\right)_{2} \mathrm{SO}_{4}, 67 \mathrm{mM}\right.$ Tris- $\mathrm{HCl} \mathrm{pH} 8.8,6.7 \mathrm{mM} \mathrm{MgCl}$, $6.7 \mu \mathrm{M}$ EDTA pH 8.8,30 mM $\beta$-mercapto-ethanol), $1.25 \mathrm{mM}$ of each deoxynucleotide (GibcoBRL), $2 \mathrm{U}$ of Taq DNA Polymerase (Cenbiot Enzimas) and $200 \mathrm{ng}$ of template DNA. Fifty $\rho \mathrm{mol} / \mu \mathrm{L}$, $70 \rho \mathrm{mol} / \mu \mathrm{L}$ and $100 \rho \mathrm{mol} / \mu \mathrm{L}$ of primers for REP, ERIC and BOXPCR, respectively were added. Amplifications were carried out using a GeneAmp PCR System 2400 Thermocycler (Perkin Elmer 
Instruments). For REP-PCR primers, cycles were as follows: initial denaturation at $95^{\circ} \mathrm{C}$ for $5 \mathrm{~min}$, followed by 35 cycles of denaturation at $94^{\circ} \mathrm{C}$ for $1 \mathrm{~min}$, annealing at $40^{\circ} \mathrm{C}$ for $1 \mathrm{~min}$ and extension at $65^{\circ} \mathrm{C}$ for $8 \mathrm{~min}$, with a final extension at $65^{\circ} \mathrm{C}$ for $16 \mathrm{~min}$. For ERIC-PCR primers, the cycles were the same except for the $50^{\circ} \mathrm{C}$ annealing temperature. However, for BOX-PCR primers, cycles were as follows: initial denaturation at $97^{\circ} \mathrm{C}$ for $5 \mathrm{~min}$, followed by 30 cycles of denaturation at $94^{\circ} \mathrm{C}$ for $1 \mathrm{~min}$, annealing at $53^{\circ} \mathrm{C}$ for $1 \mathrm{~min}$ and extension at $65^{\circ} \mathrm{C}$ for $8 \mathrm{~min}$, with a final extension at $65^{\circ} \mathrm{C}$ for $16 \mathrm{~min}$. Negative control reactions that contained every component except the target DNA were included in each experimental set. The $S$. Enteritidis ATCC 13076 was included in each set of reactions as parameter interreactions. Amplification products were electrophoresed on 1.5\% agarose gels at $5 \mathrm{~V} / \mathrm{cm}$. Gels were stained with ethidium bromide $(0.5 \mu \mathrm{g} /$ $\mathrm{mL}$ ) and visualized on a UV transiluminator. Sizes of amplicons were determined by comparison with a concurrently run DNA molecular size marker (100-bp DNA ladder, Invitrogen). Each experiment was repeated at least twice.

\section{Analysis of amplicon patterns}

Gel images containing the profiles were captured by the imaging system Ultra-Lum (Paramount, CA). The Quantity One version 4.5 software (Bio-Rad) was used for band detection, normalization, and matching. A 5\% tolerance level for matching was allowed. The REP, ERIC and BOX-PCR fingerprinting were transformed into binary code depending on the presence or absence of each band. Similarity between profiles was determined using the Jaccard coefficient and dendrograms were generated by the unweighted pair-group with mathematic average (UPGMA) method. All calculations were performed using a NTSYS-PC version 1.8 software (Applied Biostatistics).

\section{Discriminatory power of the methods}

The discriminatory power was measured by the Simpson's index of diversity $(D)$ that indicates the average probability that a typing system will assign a different type to two unrelated strains randomly sampled from a population (8).

\section{RESULTS}

\section{Phage typing, antimicrobial resistance and detection of virulence genes}

The phage typing data are summarized in Table 1. Overall, eight different phage types were detected. In the $S$. Enteritidis isolates previously analyzed, four phage types (PT4, PT4a, PT6a and PT7) had been identified (31). In this study, four additional phage types were detected (PT7a, PT6, PT11 and PT9), being three different phage types detected in the seven swine $S$. Enteritidis isolates from the same slaughterhouse, and none was PT4. The Simpson's index of diversity $(D)$ for phage typing method was 0.6. Twelve antimicrobial resistance patterns were

Table 1. Types obtained from the combination of PCR fingerprinting, phage typing, antimicrobial resistance and presence of virulence genes in Salmonella Enteritidis isolates.

\begin{tabular}{|c|c|c|c|c|c|c|c|c|c|}
\hline $\begin{array}{l}\text { Overall } \\
\text { type }\end{array}$ & $\begin{array}{l}\text { Source (number } \\
\text { of isolates) }\end{array}$ & $\begin{array}{c}\text { Year of } \\
\text { isolation }\end{array}$ & $\begin{array}{l}\text { Phage } \\
\text { type }\end{array}$ & REP & ERIC & BOX & $\begin{array}{l}\text { Antimicrobial } \\
\text { resistance }\end{array}$ & $s p v \mathrm{R}$ & $\operatorname{spvC}$ \\
\hline \multirow[t]{5}{*}{1} & Broiler carcass (5) & 1995 & 4 & R1 & $\mathrm{E} 1$ & $\mathrm{~B} 1$ & Smx & + & + \\
\hline & Broiler carcass (4) & 1996 & & & & & & & \\
\hline & Human (1) & 1995 & & & & & & & \\
\hline & Human (1) & 1996 & & & & & & & \\
\hline & Poultry (1) & $1999-2000$ & & & & & & & \\
\hline \multirow[t]{5}{*}{2} & Broiler carcass (1) & 1996 & $4 a$ & R1 & E1 & B1 & Smx, Nit & + & + \\
\hline & Food (1) & 1996 & & & & & & & \\
\hline & Human (1) & 1995 & & & & & & & \\
\hline & Human (3) & 1996 & & & & & & & \\
\hline & Poultry (6) & $1999-2000$ & & & & & & & \\
\hline 3 & Poultry (1) & $1999-2000$ & $6 a$ & R1 & $\mathrm{El}$ & $\mathrm{B} 1$ & Smx, Nit & + & + \\
\hline \multirow[t]{2}{*}{4} & Broiler carcass (1) & 1995 & 4 & R1 & $\mathrm{E} 1$ & $\mathrm{~B} 1$ & Smx, Nit & -1 & -1 \\
\hline & Broiler carcass (2) & 1996 & & & & & & & \\
\hline 5 & Broiler carcass (1) & 1996 & $4 a$ & $\mathrm{R} 1$ & $\mathrm{E} 1$ & B1 & Smx, Nit & -1 & -1 \\
\hline 6 & Human (1) & 1995 & 4 & $\mathrm{R} 1$ & E1 & $\mathrm{B} 1$ & Smx, Nit & + & -1 \\
\hline \multirow[t]{4}{*}{7} & Broiler carcass (2) & 1995 & 4 & R1 & $\mathrm{E} 1$ & $\mathrm{~B} 1$ & Smx & + & + \\
\hline & Broiler carcass (2) & 1996 & & & & & & & \\
\hline & Food (6) & 1996 & & & & & & & \\
\hline & Human (1) & 1995 & & & & & & & \\
\hline
\end{tabular}




\begin{tabular}{|c|c|c|c|c|c|c|c|c|c|}
\hline & Human (1) & 1996 & & & & & & & \\
\hline & Zimbabwe $(1)^{2}$ & - & & & & & & & \\
\hline & Tanzania $(1)^{2}$ & - & & & & & & & \\
\hline \multirow[t]{3}{*}{8} & Food (4) & 1996 & $4 a$ & $\mathrm{R} 1$ & $\mathrm{El}$ & B1 & Smx & + & + \\
\hline & Human (4) & 1996 & & & & & & & + \\
\hline & Poultry (2) & $1999-2000$ & & & & & & & + \\
\hline \multirow[t]{4}{*}{9} & Broiler carcass $(1)$ & 1995 & 4 & $\mathrm{R} 1$ & $\mathrm{E} 1$ & B1 & -3 & + & + \\
\hline & Broiler carcass (1) & 1996 & & & & & & & \\
\hline & Food (5) & 1996 & & & & & & & \\
\hline & Zimbabwe $(1)^{2}$ & - & & & & & & & \\
\hline 10 & Food (1) & 1996 & $4 a$ & $\mathrm{R} 1$ & $\mathrm{E} 1$ & B1 & -3 & + & + \\
\hline 11 & Food (1) & 1996 & $6 a$ & $\mathrm{R} 1$ & $\mathrm{El}$ & B1 & -3 & + & + \\
\hline 12 & Albania $(1)^{2}$ & - & 6 & R1 & $\mathrm{E} 1$ & B1 & -3 & + & + \\
\hline 13 & Food (5) & 1996 & 4 & $\mathrm{R} 1$ & $\mathrm{E} 1$ & B1 & Tet & + & + \\
\hline 14 & Food (1) & 1996 & 4 & $\mathrm{R} 1$ & $\mathrm{E} 1$ & B1 & Tet & -1 & + \\
\hline 15 & Food (1) & 1996 & $4 \mathrm{a}$ & $\mathrm{R} 1$ & $\mathrm{E} 1$ & B1 & Tet & + & + \\
\hline 16 & Food (1) & 1996 & 4 & $\mathrm{R} 1$ & $\mathrm{E} 1$ & B1 & Tet & $-{ }^{1}$ & -1 \\
\hline 17 & Human (1) & 1996 & 4 & $\mathrm{R} 1$ & $\mathrm{E} 1$ & B1 & Nit & + & + \\
\hline \multirow[t]{2}{*}{18} & Food (2) & 1996 & $4 a$ & R1 & $\mathrm{E} 1$ & B1 & Nit & + & + \\
\hline & Human (1) & 1996 & & & & & & & \\
\hline 19 & Swine (1) & 2000 & $6 a$ & $\mathrm{R} 1$ & $\mathrm{E} 1$ & B1 & Nit & + & + \\
\hline 20 & Swine (1) & 2000 & $7 \mathrm{a}$ & $\mathrm{R} 1$ & $\mathrm{E} 1$ & B1 & Nit & + & + \\
\hline 21 & Albania $(1)^{2}$ & - & 6 & R1 & $\mathrm{E} 1$ & B1 & Nit & + & + \\
\hline 22 & Poultry (2) & $1999-2000$ & $4 a$ & $\mathrm{R} 1$ & $\mathrm{E} 1$ & B1 & Smx, Nit, Nalx & + & + \\
\hline 23 & Poultry (1) & $1999-2000$ & 4 & $\mathrm{R} 1$ & $\mathrm{El}$ & B1 & Smx, Nit, Nalx & + & + \\
\hline 24 & Food (1) & 1996 & $4 \mathrm{a}$ & $\mathrm{R} 1$ & $\mathrm{E} 1$ & B1 & Smx, Tet, Nit & + & + \\
\hline 25 & Human (1) & 1995 & 4 & $\mathrm{R} 1$ & $\mathrm{E} 1$ & B1 & Smx, Tet, Nit & + & + \\
\hline 26 & Broiler carcass (2) & 1995 & 4 & $\mathrm{R} 3$ & $\mathrm{E} 1$ & B1 & Smx, Str, Tet, Nit & + & + \\
\hline 27 & Italy $(2)^{2}$ & - & 11 & R1 & $\mathrm{E} 1$ & B1 & Nit & + & + \\
\hline 28 & Food (1) & 1996 & 4 & $\mathrm{R} 1$ & $\mathrm{E} 1$ & B1 & Nalx & + & + \\
\hline 29 & Food (1) & 1996 & 4 & $\mathrm{R} 1$ & $\mathrm{E} 2$ & B1 & Tmp & + & + \\
\hline 30 & Human (1) & 1995 & 4 & $\mathrm{R} 1$ & $\mathrm{E} 1$ & B1 & Smx, Tmp, Tet, Nit & + & + \\
\hline 31 & Poultry (1) & $1999-2000$ & 4 & $\mathrm{R} 1$ & $\mathrm{E} 1$ & B1 & Smx, Str, Gen & + & + \\
\hline 32 & Poultry (1) & $1999-2000$ & 4 & R1 & $\mathrm{E} 1$ & B1 & Smx, Str, Nor, Gen, Nit, Nalx & + & + \\
\hline 33 & Poultry (1) & $1999-2000$ & $4 \mathrm{a}$ & $\mathrm{R} 1$ & $\mathrm{E} 1$ & $\mathrm{~B} 1$ & Smx, Str, Nor, Gen, Nit & + & -1 \\
\hline 34 & Poultry (1) & $1999-2000$ & $4 \mathrm{a}$ & $\mathrm{R} 1$ & $\mathrm{E} 1$ & $\mathrm{~B} 1$ & Chl, Smx, Tmp, Str, Gen, Cef, Ampc & + & + \\
\hline 35 & Poultry (1) & $1999-2000$ & $4 a$ & $\mathrm{R} 1$ & $\mathrm{E} 1$ & B1 & Smx, Str, Tet, Gen, Nit & $-{ }^{1}$ & -1 \\
\hline 36 & Poultry (1) & $1999-2000$ & $4 \mathrm{a}$ & R1 & $\mathrm{E} 1$ & $\mathrm{~B} 1$ & Smx, Nit, Nalx, Cef & + & + \\
\hline 37 & Poultry (1) & $1999-2000$ & 7 & $\mathrm{R} 1$ & $\mathrm{E} 1$ & $\mathrm{~B} 1$ & Smx, Str, Gen, Nit & + & + \\
\hline 38 & Poultry (1) & $1999-2000$ & 4 & $\mathrm{R} 1$ & $\mathrm{E} 1$ & B1 & Smx, Nalx & + & + \\
\hline 39 & Swine (1) & 2000 & $6 a$ & $\mathrm{R} 1$ & $\mathrm{E} 1$ & $\mathrm{~B} 1$ & Str, Nit & + & + \\
\hline 40 & Swine (1) & 2000 & 6 & R1 & $\mathrm{E} 1$ & B1 & Smx, Str, Nit, Ampc & + & + \\
\hline 41 & Swine (2) & 2001 & $6 a$ & $\mathrm{R} 1$ & $\mathrm{E} 1$ & B1 & Str, Tet, Gen, Nit & + & + \\
\hline 42 & Swine (1) & 2001 & $6 a$ & $\mathrm{R} 1$ & $\mathrm{E} 1$ & B1 & Smx, Str, Tet, Gen & + & + \\
\hline 43 & Swine (1) & 2001 & $\mathrm{ND}$ & $\mathrm{R} 1$ & $\mathrm{E} 1$ & B2 & Chl, Smx, Tet, Nit, Nalx & -1 & -1 \\
\hline 44 & Swine (1) & 2000 & $\mathrm{ND}$ & $\mathrm{R} 1$ & $\mathrm{E} 1$ & B1 & Gen, Nit & + & + \\
\hline 45 & Swine (1) & 1999 & $\mathrm{ND}$ & R1 & $\mathrm{E} 1$ & B1 & Str, Nalx & + & + \\
\hline 46 & Swine (1) & 2000 & $\mathrm{ND}$ & R1 & $\mathrm{E} 1$ & B1 & Smx, Nit & + & + \\
\hline 47 & Egypt $(1)^{2}$ & - & 4 & $\mathrm{R} 1$ & $\mathrm{E} 1$ & $\mathrm{~B} 1$ & Smx, Str, Nit & + & + \\
\hline 48 & Tanzania $(1)^{2}$ & - & 9 & $\mathrm{R} 2$ & $\mathrm{El}$ & B3 & Chl, Smx, Str, Ampc & + & + \\
\hline
\end{tabular}

${ }^{1}$ not detected; ${ }^{2}$ source and year of isolation are not known, only country of origin; ${ }^{3}$ sensitive to all antimicrobial drugs tested; ND=Not determined. 
found in isolates from pig and other countries (Table 1). Resistance to cephalotin, ciprofloxacin, gentamicin, and norfloxacin was not detected. Considering all 111 isolates, 27 different resistance patterns were observed, showing a $D$ value of 0.86 . The virulence genes $i n v \mathrm{~A}, s p v \mathrm{R}$ and $s p v \mathrm{C}$ were detected in all isolates from other countries. Taking together all 111 isolates, the virulence genes $i n v \mathrm{~A}, s p v \mathrm{R}$ and $s p v \mathrm{C}$ were detected in $100 \%, 91.2 \%$ and $91 \%$, respectively.

\section{rep-PCR fingerprinting}

Profiles could be discriminated by the number and position of amplified DNA bands. In order to determine the reproducibility of PCR fingerprinting, duplicate samples were analyzed at different times. Electrophoreses in agarose gels were performed at the same time, with each isolate running side-by-side. Different patterns were not obtained from the same sample, although differences in band intensity were sometimes observed. The very weak bands were not reproducible, and were therefore not taken into account. Many bands were larger than about $1500 \mathrm{bp}$ and difficult to resolve. Bands between about 140 and $1500 \mathrm{bp}$ were less numerous, better resolved, and therefore, useful for matching fingerprints. Most rep-PCR profiles were similar, except for the presence or absence of one or few DNA fragments.

\section{REP-PCR fingerprinting}

With the primer combination REP1R4-I and REP2-I, three different profiles were found: R1, R2 and R3 (Fig. 1). The number of bands per profile varied from 9 to 12 bands ranging between about $140 \mathrm{bp}$ to $1340 \mathrm{bp}$. Conserved fragments of approximately $235,590,725,785,985,1050$ and $1340 \mathrm{bp}$ were found in all $S$. Enteritidis isolates. Weak fragments of approximately 450 and $625 \mathrm{bp}$ were also found in the same isolates. The fragments of approximately 235, 590, 725, 785, 985 and 1050 were also conserved in the other serovars tested. Profile R1 showed all bands mentioned above. Profiles R2 and R3 showed the same bands as R1, with some additional bands. Profile R2 was characterized by the presence of one weak fragment of approximately $135 \mathrm{bp}$ and two additional fragments of approximately 305 and $500 \mathrm{bp}$. Profile R3 showed two additional fragments as compared to R1 of approximately 160 and $350 \mathrm{bp}$. The three profiles were clustered at $71.4 \%$ similarity. Profiles R1 and R3 formed a single cluster at $81.8 \%$ similarity. The $S$. Typhimurium isolate displayed profile $\mathrm{R} 1$, but the other serovars formed a different cluster with similarity below 70\%. Most of the isolates (108/111) belonged to profile R1, while profile R2 was found only in one of the isolates from Tanzania (isolate 111 ) and R3 in two isolates from broiler carcasses (isolates 14 and 15). The $D$ value for this typing method was 0.05 .

\section{ERIC-PCR fingerprinting}

With the ERIC set of primers, three profiles were also observed and referred to as E1, E2 and E3 (Fig. 2). The size of

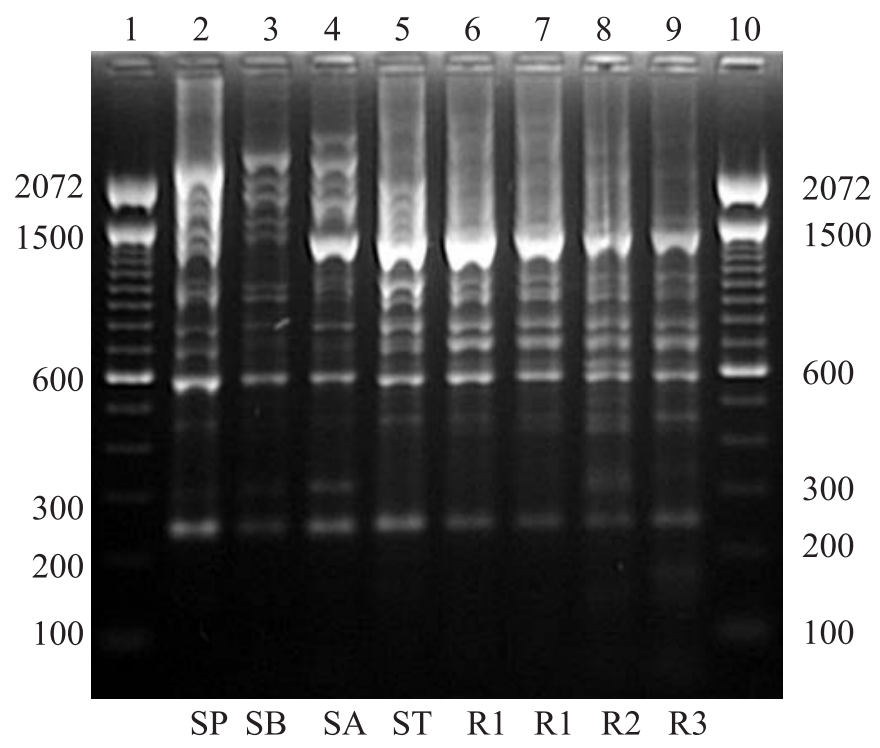

Figure 1. Electrophoreses of REP-PCR products on $1.5 \%$ agarose gel stained with ethidium bromide: $100 \mathrm{bp}$ molecular size marker (lane 1 and 10); profile R1 (lane 6 and 7); profile R2 (lane 8); profile R3 (lane 9); amplification products from DNA of $S$. Panama (lane 2); $S$. Bredeney (lane 3); $S$. Agona (lane 4); $S$. Typhimurium (lane 5).

amplification products ranged from about $190 \mathrm{bp}$ to $1430 \mathrm{bp}$ forming profiles with 12 or 13 bands each. Profile E1 showed fragments of approximately 190, 235, 370, 415, 480, 685, 730, $800,925,1040,1150$ and $1390 \mathrm{bp}$. These fragments were also found in profiles E2 and E3. Conserved amplicons of approximately 235, 685 and 800 bp were also found in the other serovars tested. Profile E2 differed from E1 by the presence of one intense fragment of approximately $590 \mathrm{bp}$. Profile E3 also showed only one additional fragment of approximately $275 \mathrm{bp}$. Whereas profile E1 was found in $110 \mathrm{~S}$. Enteritidis isolates, only one isolate from food (isolate 59) belonged to profile E2, and profile E3 was only present in the ATCC strain. Profiles E1, E2 and E3 formed a single cluster at 89\% similarity level, being E1 and E2 clustered at 92.3\% similarity. $S$. Typhimurium and $S$. Panama isolates showed similarity with the cluster formed by E1, E2 and E3 at 79.2\% and 75\%, respectively. $S$. Agona and $S$. Bredeney isolates formed a different cluster at similarity below $70 \%$. The $D$ value for this typing method was 0.04 .

\section{BOX-PCR fingerprinting}

By BOX-PCR with primer BOXA1R, three different profiles were found: B1, B2 and B3 (Fig. 3). The size of amplification products ranged from about $140 \mathrm{bp}$ to $1230 \mathrm{bp}$. Profiles showed eight or nine bands. All $S$. Enteritidis isolates were characterized 


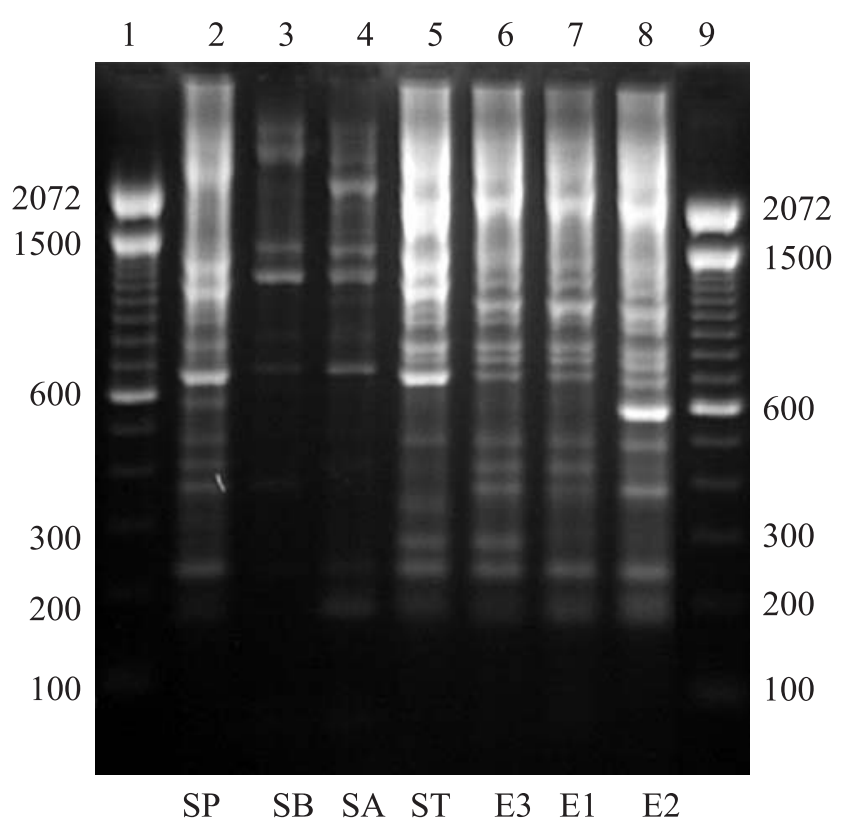

Figure 2. Electrophoreses of ERIC-PCR products on $1.5 \%$ agarose gel stained with ethidium bromide: $100 \mathrm{bp}$ molecular size marker (lane 1 and 9); profile E1 (lane 7); profile E2 (lane 8); profile E3 (lane 6); amplification products from DNA of $S$. Panama (lane 2); $S$. Bredeney (lane 3); S. Agona (lane 4); S. Typhimurium (lane 5).

by the presence of amplicons of approximately 140, 245, 440, $565,665,860$ and $1230 \mathrm{bp}$. A conserved fragment of approximately $665 \mathrm{bp}$ was also found in the other serovars. Profile B1 showed nine DNA bands as follows: approximately 140, 245, 380, 440, $565,665,860,1080$ and 1230 bp. Profile B2 differed from B1 by the presence of one fragment of approximately $750 \mathrm{bp}$ and the absence of the fragment of approximately $1080 \mathrm{bp}$. The profile B3 showed the same fragments as B1, except for fragment of $380 \mathrm{bp}$. The majority of the $S$. Enteritidis isolates belonged to profile B1. Profile B2 was represented only by one isolate from swine (isolate 99). BOX-PCR, as well as REP-PCR, discriminated one of the isolates from Tanzania (isolate 111), which formed alone the profile B3. All $S$. Enteritidis were clustered at $85.6 \%$ similarity. Profiles B1 and B3 formed a single cluster with $94.1 \%$ similarity. The $S$. Enteritidis and other serovars were clustered at below $70 \%$ of similarity. The $D$ value for this typing method was 0.04 .

\section{Combination of the typing methods}

The combination of the results described above with those obtained in previous studies for phage typing, presence of virulence genes and antimicrobial resistance pattern $(23,24,31)$ permitted the identification of a total of 48 types (Table 1 ). Types $1,2,7,8$ and 9 were the most prevalent, being found in 56

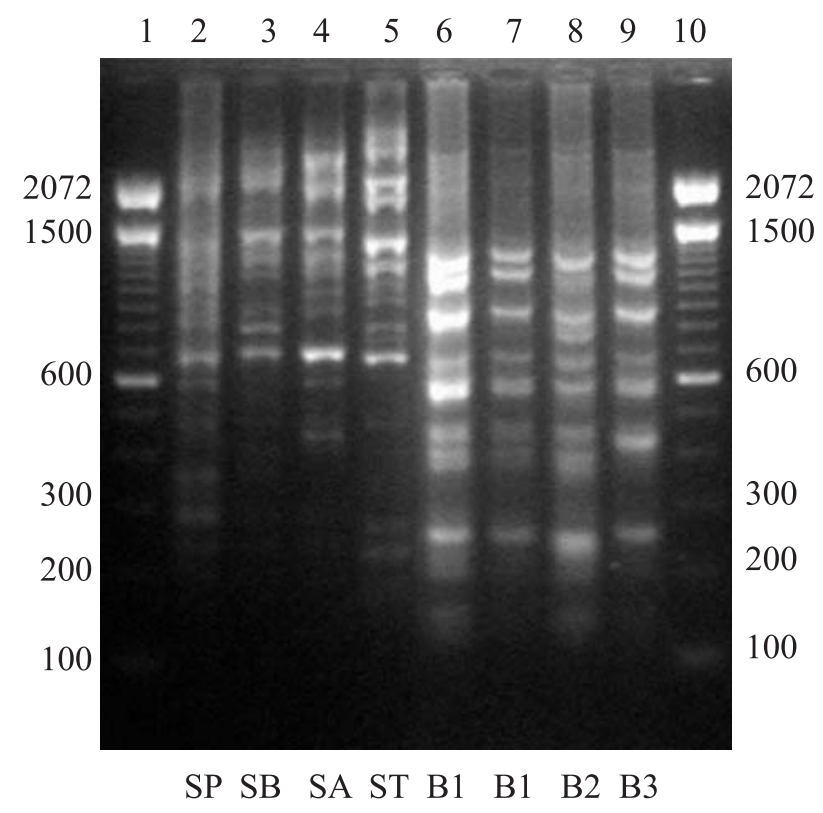

Figure 3. Electrophoreses of BOX-PCR products on $1.5 \%$ agarose gel stained with ethidium bromide: $100 \mathrm{bp}$ molecular size marker (lane 1 and 10); profile B1 (lane 6 and 7); profile B2 (lane 8); profile B3 (lane 9); amplification products from DNA of $S$. Panama (lane 2); $S$. Bredeney (lane 3); $S$. Agona (lane 4); $S$. Typhimurium (lane 5).

isolates. No type was found in all the different sources (broiler carcasses, food, human samples, poultry and swine samples). Types 2 and 7 were more disseminated between sources, being the former found in broiler carcasses, food, human samples and poultry, and the latter found in broiler carcasses, food, human samples and isolates from other countries. Types 1, 2, 7, 8, 9 and 18 were the only types found in more than one source. The data obtained afforded the construction of a dendrogram to show similarity levels between isolates (Fig. 4).

\section{DISCUSSION}

It is of great public health significance that strains of $S$. Enteritidis can be rapidly identified and distinguished; therefore in the present study we investigated the suitability of rep-PCR fingerprinting to discriminate among $S$. Enteritidis isolates. Furthermore, we assessed whether the combination of rep-PCR with phage typing, presence of virulence genes and antimicrobial resistance could increase the discrimination between the isolates.

PCR fingerprinting with three primer sets showed that the majority of the isolates belonged to the same profile (R1E1B1). Most of these isolates had been formerly analyzed by Santos (2001), who obtained only one pattern using RAPD with primers 


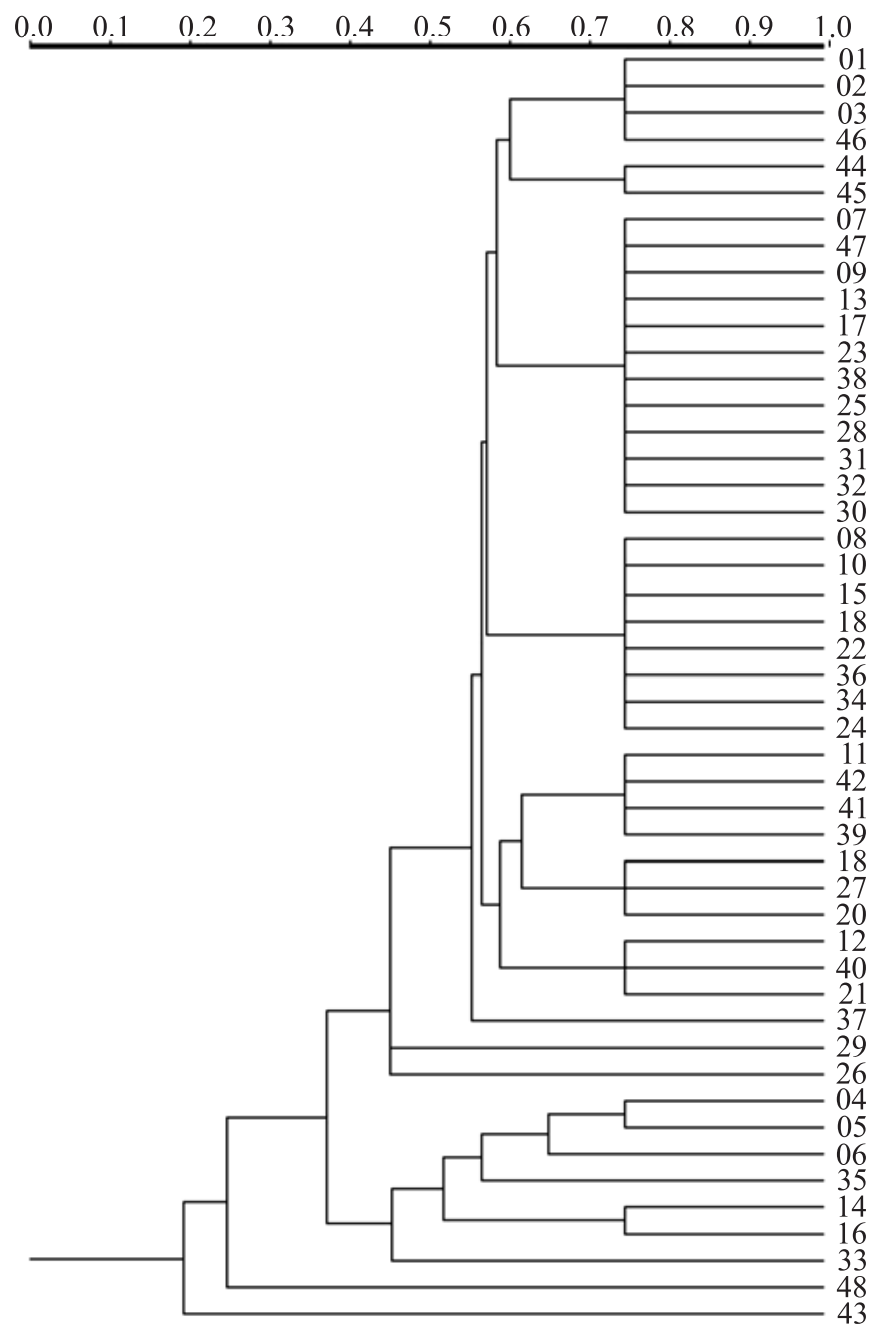

Figure 4. Dendrogram of the cluster analysis based on combination of PCR fingerprinting, phage typing, antimicrobial resistance and presence of virulence genes in Salmonella Enteritidis isolates. The designation of each type is given on the vertical axis. The numbers on the horizontal axis indicate the percentage similarities as determined by the Jaccard coefficient and UPGMA clustering.

OPB17 and 1254. These results can be explained in three different ways: the majority of isolates belong to the same clonal lineage, rep-PCR cannot discriminate among them, or both hypothesis. Probably, the third hypothesis is the most probable, since the majority of the $S$. Enteritidis isolates analyzed belonged to PT4 or PT4a, considered highly clonal. Therefore, the high homogeneity detected among isolates, even with those obtained from other countries and thus unrelated with the local strains, indicates the low discriminatory power of rep-PCR for $S$. Enteritidis.
The great heterogeneity found by Chmielewski et al. (2002) using REP- and ERIC-PCR in $31 \mathrm{~S}$. Enteritidis isolates stimulated our study. According to these authors, the two methods were shown to be highly discriminatory and useful for epidemiological evaluation of the serovar Enteritidis. The differences found in REP-PCR can be due to the fact that the REP primers used were different from those used in the present study. However, the ERIC primers were the same and the protocol for DNA purification was similar, which does not justify the differences found in the ERIC-PCR results from the two works. Weigel et al. (2001) also used rep-PCR with the same primers tested in the present study to type Salmonella and compared the profiles obtained with those generated by PFGE after DNA cleavage with three different enzymes. According to these authors, both methods were equivalent in detecting genetic variance and neither revealed improbable patterns of transmission. However, these authors did not specify which Salmonella serovars were tested, and probably they analyzed serovars with more genetic variance as compared to Enteritidis. A high discriminatory power also was found by Rasschaert et al. (2005), since divided $13 \mathrm{~S}$. Enteritidis into six clusters using the same ERIC primer set used in the present study. However, the differences found in the fingerprints of these strains consisted in bands of different intensity at $2000 \mathrm{bp}$, a size that was not analyzed in the present study, because bands larger than about 1500 bp displayed low resolution power in our experiments, what can explain the differences from our results.

The high level of similarity between $S$. Enteritidis and $S$. Typhimurium detected by REP-PCR is in accordance with findings of Millemann et al. (1996) for ERIC-PCR. They identified just two patterns that differed by a single band in $56 \mathrm{~S}$. Typhimurium and $14 S$. Enteritidis isolated from poultry. All 14 $S$. Enteritidis and seven $S$. Typhimurium isolates generated the same pattern. Our results and the findings of Millemann et al. (1996) and Burr et al. (1998), using the same primers, are in disagreement with those described by Van Lith and Aarts (1994) and Koh-Luar et al. (1998), who found each serotype to be characterized by a unique DNA profile. Burr et al. (1998) characterized other Salmonella serovars and found that every isolate had a unique fingerprinting but the serovars were not grouped together in major branches. Thus, serotypes were not identified by ERIC-PCR.

The low discriminatory power of rep-PCR for typing $S$. Enteritidis described in the present study was also found by other authors that used other genotypic methods as PFGE, considered the gold standard for Salmonella typing $(7,12,13)$. Despite, one Brazilian study using ribotyping discriminated 14 ribotypes, six being identified within PT 8 and three within PT 4 isolates (4).

The high prevalence of virulence genes together with the genetic homogeneity between $S$. Enteritidis isolates detected in the present study are in accordance with Burr et al. (1998) 
that suggested that the requirement for invasion and virulence factors selected a more homogeneous subpopulation.

No correlation between fingerprints, year and place of isolation could be traced. We were also unable to correlate a particular rep-PCR profile with PT, with exception of the PT9 isolate, which also showed unique profiles in REP and BOXPCR. However, there was a correlation between the less frequent rep-PCR profiles and unique antimicrobial resistance patterns (Table 1). Although few strains isolated from swine were analyzed, we observed differences in the antimicrobial resistance pattern of this isolates that are probably a consequence of the different drugs used in chicken and swine rearing. Furthermore, phage type 4 was not found in swine. repPCR showed a lower discriminatory power as compared to phage typing and antimicrobial resistance. However, the combination of the different methods improved the discriminatory power among $S$. Enteritidis isolates, even though the same antimicrobial resistance pattern did not necessarily reflect genetic relatedness. The collection of $111 \mathrm{~S}$. Enteritidis isolates was further differentiated into 48 types by combining the rep-PCR patterns with phage types, presence of virulence genes and antimicrobial resistance profiles. When all methods were combined, the majority of isolates from swine displayed single profiles, indicating that the source of the bacteria probably is not the same.

In conclusion, we found that rep-PCR performed as described in the present study was not useful for $S$. Enteritidis typing, because it was not able to discriminate potentially different isolates. However, the combined use of genotypic and phenotypic methods allowed a more accurate discrimination between isolates.

\section{ACKNOWLEDGEMENTS}

We thank S. Rubino from Universitá di Sassari for providing Salmonella Enteritidis from other countries. Financial support was provided by Fundação de Amparo à Pesquisa do Estado do Rio Grande do Sul (FAPERGS) and Conselho Nacional de Desenvolvimento Científico e Tecnológico (CNPq).

\section{RESUMO}

\section{Caracterização fenotípica e genotípica de isolados de Salmonella Enteritidis}

Uma caracterização detalhada de Salmonella Enteritidis é necessária para que possa ser desenvolvido o estudo da epidemiologia dos surtos causados por este organismo, bem como a determinação da fonte de contaminação, evitando que ocorram novos surtos. Assim, o objetivo deste estudo foi verificar se a rep-PCR era capaz de diferenciar isolados de $S$. Enteritidis. A fagotipagem, a detecção de genes de virulência e a determinação de resistência antimicrobiana foram associadas aos resultados da rep-PCR. Cento e duas $S$. Enteritidis isoladas de carcaças de frango, alimentos prontos para consumo, humanos suínos, amostras relacionadas a aves, e nove isolados de outros países foram genotipicamente tipados por REP-PCR, ERIC-PCR e BOX-PCR, juntamente chamados de rep-PCR. A fagotipagem, a detecção de genes de virulência e a determinação de resistência antimicrobiana também foram realizadas. Somente três padrões de fingerprinting foram obtidos com cada método de rep-PCR, sendo que a maioria dos isolados pertenceu ao mesmo perfil. Nenhuma relação foi observada entre o perfil genotípico e o ano, o local de isolamento e a fonte de infecção. Entretanto, os perfis menos freqüentes de rep-PCR apresentaram padrões de resistência antimicrobiana únicos. Embora poucas amostras de suínos tenham sido analisadas, diferentes padrões de resistência antimicrobiana foram observados. Além disso, o fagotipo 4 não foi encontrado em isolados de suínos. A repPCR apresentou um menor poder discriminatório quando comparada com a resistência antimicrobiana e com a fagotipagem, mas a combinação dos métodos genotípicos e fenotípicos foi mais discriminatória do que qualquer método isolado, resultando em 48 tipos diferentes.

Palavras-chave: Salmonella Enteritidis, rep-PCR, fagotipagem, resistência antimicrobiana e genes de virulência

\section{REFERENCES}

1. Burr, M.D.; Josephson, K.L.; Pepper, I.L. (1998). An evaluation of ERIC PCR and AP PCR fingerprinting for discriminating Salmonella serotypes. Lett Appl. Microbiol., 27, 24-30.

2. Chmielewski, R.; Wieliczko, A.; Kuczkowski, M.; Mazurkiewicz, M.; Ugorski, M. (2002). Comparison of ITS profiling, REP- and ERIC-PCR of Salmonella Enteritidis isolates from Poland. J. Vet. Med., 49, 163-168.

3. Fantasia, M.; Filetici, E. (1994). Salmonella enteritidis in Italy. Int J. Food Microbiol., 21, 7-13.

4. Fernandes S.A. et al. (2003). Phenotypic and molecular characterization of Salmonella Enteritidis strains isolated in Sao Paulo, Brazil. Rev. Inst. Med. Trop. São Paulo; 45: 59-63.

5. Fuzihara, T.O.; Fernandes, S.A.; Franco, B.D. (2000). Prevalence and dissemination of Salmonella serotypes along the slaughtering process in Brazilian small poultry slaughter-houses. J. Food Prot., 63, 1749-1753.

6. Hofer, E.; Silva Filho, S.J.; Reis, E.M.F. (1997). Prevalência de sorovares de Salmonella isolados de aves no Brasil. Pesqui. Vet. Bras. 17, 55-62.

7. Hudson, C.R.; Garcia, M.; Gast, R.K.; Maurer, J.J. (2001). Determination of close genetic relatedness of the major Salmonella enteritidis phage types by pulsed-field gel electrophresis and DNA sequence analysis of several Salmonella virulence genes. Avian Dis. 48, 875-886.

8. Hunter, P.R. (1990). Reproducibility and indices of discriminatory power of microbial typing methods. J. Clin. Microbiol., 28, 19031905.

9. Kang, H.P.; Dunne, W.M. (2003). Stability of repetitive-sequence PCR patterns with respect to culture age and subculture frequency. $J$. Clin. Microbiol., 41, 2694-2696. 
10. Khakhria, R.; Woodward, D.; Johnson, W.M.; Poppe, C. (1997). Salmonella isolated from humans, animals and other sources in Canada. Epidemiol. Infect., 119, 15-23.

11. Koh-Luar, S.I.; Choo, G.H.B.; Tan, S.L.R.; Tan, C.W.K. (1998). Genomic fingerprintings of Salmonella species generated with repetitive element sequence-based PCR. World J. Microbiol. Biotechnol., 14, 17-22.

12. Kotetishvili, M.; Stine, O.C.; Kreger, A.; Morris Jr., J.G.; Sulakvelidze, A. (2002). Multilocus sequence typing for characterization of clinical and environmental Salmonella strains. J. Clin. Microbiol., 40, 16261635 .

13. Liebana, E.; Garcia-Migura, L.; Breslin, M.F.; Davies, R.H.; Woodward, M.J. (2001). Diversity of strains of Salmonella enterica serotype Enteritidis from English poultry farms assessed by multiple genetic fingerprinting. J. Clin. Microbiol., 39, 154-161.

14. Lin, A.W.; Usera, M.A.; Barret, T.J.; Goldsby, R.A. (1996). Application of random amplified polymorphic DNA analysis to differentiate strains of Salmonella enteritidis. J. Clin. Microbiol., 34, 870-876.

15. Lindstedt, B.A.; Heir, E.; Vardund, T.; Kapperud, G. (2000). Fluorescent amplified-fragment length polymorphism genotyping of Salmonella enterica subsp. enterica serovars and comparison with pulsed-field gel electrophoresis typing. J. Clin. Microbiol., 38, 1623-1627.

16. Ling, J.M.; Koo, I.C.; Kam, K.M.; Cheng, A.F. (1998). Antimicrobial susceptibilities and molecular epidemiology of Salmonella enterica serotype Enteritidis strains isolated in Hong Kong from 1986 to 1996. J. Clin. Microbiol., 36, 1693-1699.

17. Liu, P.Y.; Lau, Y.J.; Hu, B.S.; Shyr, J.M.; Shi, Z.Y.; Tsai, W.S.; Lin, Y.H.; Tseng, C.Y. (1995). Analysis of clonal relationships among isolates of Shigella sonnei by different molecular typing methods. $J$. Clin. Microbiol. 33, 1779-1783.

18. Lupski, J.R.; Weinstock, G.M. (1992). Short, interspersed repetitive DNA sequences in prokaryotic genomes. J. Bacteriol., 174, 45254529.

19. Maiden, M.C.; Bygraves, J.A.; Feil, E.; Morelli, G.; Russel, J.E.; Urwin, R.; Zhang, Q.; Zhou, J.; Zurth, K.; Caugant, D.A.; Feavers, I.M.; Achtman, M.; Spratt, B.G. (1998). Multilocus sequence typing: a portable approach to the identification of clones within populations of pathogenic microorganisms. Proc. Natl. Acad. Sci. U.S.A., 95, 3140-3145.

20. Millemann, Y.; Lesage-Descauses, M.C.; Chaslus-Dancla, E.; Lafont, J.P. (1995). Value of plasmid profiling, ribotyping and detection of IS200 for tracing avian isolates of Salmonella typhimurium and enteritidis. J. Clin. Microbiol., 33, 173-179.

21. Millemann, Y.; Lesage-Descauses, M.C.; Lafont, J.P.; Chaslus-Dancla, E. (1996). Comparison of random amplified polymorphic DNA analysis and enterobacterial repetitive intergenic consensus-PCR for epidemiological studies of Salmonella. FEMS Immunol. Med. Microbiol., 14, 129-134.

22. NCCLS (2001). Performance standards for antimicrobial susceptibility testing; 11th informational supplement. Approved standard M2-A7 and M7-A5. Natl. Comm. Clin. Lab. Stand., Wayne, PA, USA.

23. Oliveira, S.D.; Flores, F.S.; Santos, L.R.; Brandelli, A. (2005). Antimicrobial resistance in Salmonella Enteritidis strains isolated from broiler carcasses, food, human and poultry-related samples. Int. J. Food Microbiol., 97, 297-305.

24. Oliveira, S.D.; Rodenbusch, C.R.; Michael, G.; Cardoso, M.I.R.; Canal, C.W.; Brandelli, A. (2003). Detection of virulence genes in Salmonella Enteritidis isolated from different sources. Braz. J. Microbiol., 34, 123-124.

25. Peresi, J.T.M.; Almeida, I.A.Z.C.; Lima, S.I.; Marques, D.F.; Rodrigues, E.C.A.; Fernandes, S.A.; Gelli, D.S.; Irino, K. (1998). Surtos de enfermidades transmitidas por alimentos causados por Salmonella Enteritidis. Rev. Saude Publica, 32, 477-483.

26. Rademaker, J.L.W.; Bruijn, F.J. (1997). Characterization and classification of microbes by REP-PCR genomic fingerprinting and computer-assisted pattern analysis. In Caetano-Anollés, G, Gresshoff, P. M. (Eds.), DNA markers: protocols, applications, and overviews. J. Wiley Sons., New York, pp.151-171.

27. Rasschaert, G.; Houf, K.; Imberechts, H.; Grijspeerdt, K.; De Zutter, L.; Heyndrickx, M. (2005). Comparison of five repetitive-sequencebased PCR typing methods for molecular discrimination of Salmonella enterica isolates. J. Clin. Microbiol., 43, 3615-3623.

28. Rodrigue, D.C.; Tauxe, R.V.; Rowe, B. (1990). International increase in Salmonella Enteritidis: a new pandemic? Epidemiol. Infect., 105, 21-27.

29. Santos, D.M.S.; Berchieri Junior, A.; Fernandes, S.A.; Tavechio, A.T.; Amaral, L.A. (2000). Salmonella em carcaças de frango congeladas. Pesq. Vet. Bras., 20, 39-42.

30. Santos, L.R. (2001). Fagotipagem e análise por RAPD/PCR (DNA Polimórfico Amplificado ao Acaso) de amostras de Salmonella Enteritidis isoladas de materiais de origem avícola e de alimentos e humanos envolvidos em casos de toxinfecções alimentares. M. D. thesis, Universidade Federal do Rio Grande do Sul, Porto Alegre, Brazil.

31. Santos, L.R.; Nascimento, V.P.; Oliveira, S.D.; Rodrigues, D.P.; Reis, E.M.F.; Seki, L.M.; Ribeiro, A.R.; Fernandes, S.A. (2003). Phage types of Salmonella Enteritidis isolated from clinical and food samples, and from broiler carcasses in Southern Brazil. Rev. Inst. Med. Trop. São Paulo, 45, 1-4.

32. Tassios, P.T.; Markogiannakis, A.; Vatopoulos, A.C.; Katsanikou, E.; Velonakis, E.N.; Kourea-Kremastinou, J.; Legakis, N.J. (1997). Molecular epidemiology of antibiotic resistance of Salmonella enteritidis during a 7-year period in Greece. J. Clin. Microbiol., 35, 1316-1321.

33. Tavechio, A.T.; Fernandes, S.A.; Neves, B.C.; Dias, A.M.G.; Irino, K. (1996). Changing patterns of Salmonella serovars: increase of Salmonella Enteritidis in São Paulo, Brazil. Rev. Inst. Med. Trop. São Paulo, 38, 315-322.

34. Tavechio, A.T.; Ghilardi, A.C.; Peresi, J.T.; Fuzihara, T.O.; Yonamine, E.K.; Jakabi, M.; Fernandes, S.A. (2002). Salmonella serotypes isolated from nonhuman sources in São Paulo, Brazil, from 1996 through 2000. J. Food Prot., 65, 1041-1044.

35. Thong, K.L.; Ngeow, Y.F.; Altwegg, M.; Navaratnam, P.; Pang, T. (1995). Molecular analysis of Salmonella enteritidis by pulsed-field gel electrophoresis and ribotyping. J. Clin. Microbiol., 33, 10701074.

36. Tompkins, L.S.; Troup, N.; Labaigne-Roussel, A.; Cohen, M. (1986). Cloned random chromosomal sequences as probes to identify Salmonella species. J. Infect. Dis., 154, 156-162.

37. Van Lith, L.A.J.T.; Aarts, H.J.M. (1994). Polymerase chain reaction identification of Salmonella serotypes. Lett. Appl. Microbiol., 19, 273-276.

38. Versalovic, J.; Koeuth, T.; Lupski, J.R. (1991). Distribution of repetitive DNA sequences in eubacteria and application to fingerprinting of bacterial genomes. Nucleic Acids Res., 19, 6823-6831.

39. Versalovic, J.; Schneider, M.; Bruijn, F.J.; Lupski, J.R. (1994). Genomic fingerprinting of bacteria using repetitive sequence-based polymerase chain reaction. Methods Mol. Cell. Biol., 5, 25-40.

40. Weigel, R.M.; Qiao, B.; Barber, D.A.; Teferedegne, N.B.; Kocherginskaya, S.; White, B.A.; Isaacson, R.E. (2001). Identification of patterns of transmission of Salmonella within swine production systems using pulsed field gel electrophoresis (PFGE) and repetitive sequence polymerase chain reaction (REP-PCR): a quantitative analysis. Berl. Munch. Tierarztl. Wochenschr., 114, 397-400. 